\title{
Designing of the Air Plant Holding Equipment for Tillandsia cotton candy as Green Roof
}

\author{
Kanokkan Noisuk ${ }^{1}$, Juntakan Taweekun ${ }^{2}$ and Kuaanan Techato ${ }^{3}$
}

\begin{abstract}
This paper presents an experimental study on the Designing of the Air Plant holding equipment for the Tillandsia cotton candy as Green Roof, the properties of resistance to weather, plants grow normally, and the cost is minimal. The selection of materials on properties must not have the effect to the growth of plants and environment friendly. In experimental models have built roofs meters long, one meter wide and one meter high, one of the three rear-mounted Roofing tile roofs with a slope of 30 degrees. The study found that these three types of materials used, not affect the plant's growth forecast. The roof is made of plastic water bottles. Aluminum wire and aluminum cladding plastid can remain dormant in hot weather and rain.
\end{abstract}

Keywords - Eco Design, Green roof, Air plant.

\section{INTRODUCTION}

$\mathrm{T}$ HE idea of growing plant on the roof to reduce heat transfer to the houses or buildings has to confront with the problem of watering, fertilizing, and other maintenance. The air plant which is xerophyte, epiphyte, and growth retardant seems to be solution to reduce the confront problem. The Tillandsia Cotton Candy is able to be used as green roof but there is the problem of holding it on the roof. This study therefore aimed at designing the holding equipment to be used as green roof. The holding equipment must be cheap, able to hold, weather proof, and not interfere the growth of plant

\section{LITERATURE REVIEW}

Tillandsia is a kind of air plant in the Bromeliaceae. The origin is hot and dry area causes the plant is xerophyte. In this study the Tillandsia Cotton Candy is used because it is epiphyte and growth retardant. The scale leaves on the plant can absorb the dust and mineral for plant and also moister as water. The maintenance for the plant is therefore almost zero maintenance if the plant is placed in the right condition. Trichrome is therefore appropriate to be the air plant green roof. [1] , [2]

\section{Methodology}

Search the material and cost from the construction database. The property for selection is cheap, antirust, weather proof,

\footnotetext{
${ }^{1 \text { and } 3}$ Faculty of Environmental Management, Songkla University. Songkla 90112, Thailand.

${ }^{2}$ Department of Mechanical Engineering, Faculty of Engineering, Prince of Songkla University, Songkla 90112, Thailand.
}

light, low conductivity, easy to process, and environmental friendly. Bring the selected material and design as air plant holding equipment for 3 options. The 30 degree inclined angle roof is used in the experiment. The holding equipment should leave the distance between air plant and roof around $15 \mathrm{~cm}$ to avoid the molding formation. The 3 options of holding equipment are attached to the experimental roof and place in the real weather for 12 months.

\section{RESUlt AND DisCUSSION}

The property of the material used as holding equipment must be antirust, light, low conductivity, reasonable price, formable, and environmental friendly as shown in Table 1.

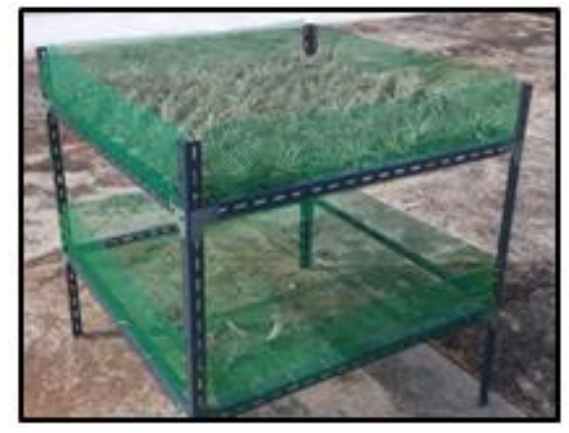

Fig. 1

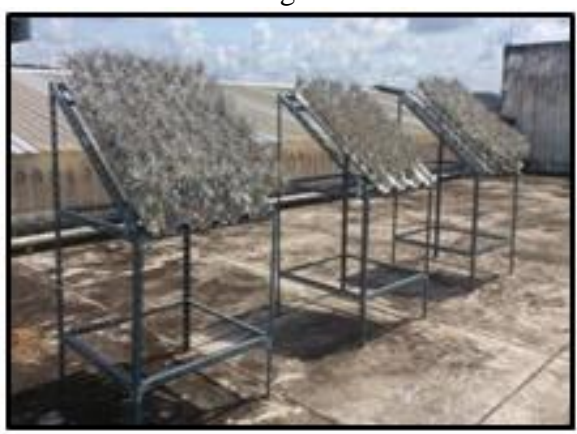

Fig. 2

Figure 1. The controlled set of experiment

Figure 2. The experiment for 3 type of holding equipment 


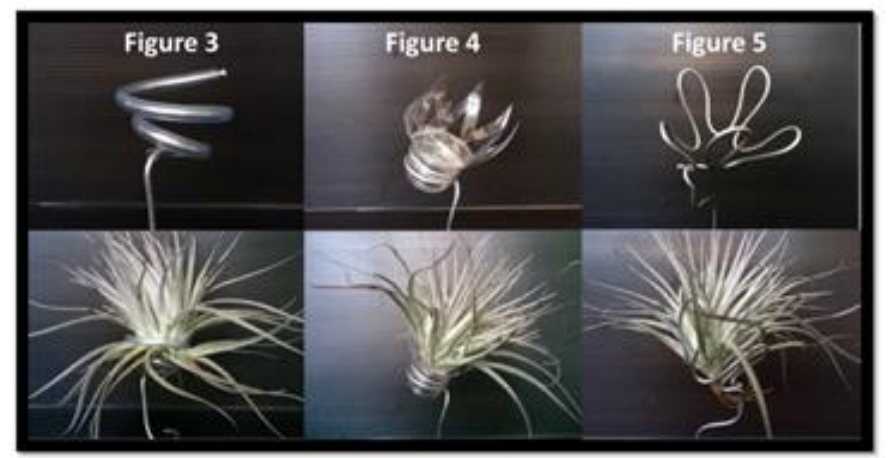

Figure 3 Type 1 Plastic cladding aluminum rod

Figure 4 Type 2 Plastic bottle

Figure 5 Type 3 Aluminum rod

The holding equipment has no effect to the growth of plant which can be seen from comparing the growth rate of the controlled set and the experiment for 3 types of holding equipment (see table 2.)

TABLE I

THE PROPERTY OF THE MATERIAL USED AS HOLDING

\begin{tabular}{|l|c|c|c|c|c|c|c|}
\hline \multicolumn{1}{|c|}{ Design Type } & Antirust & $\begin{array}{c}\text { Density } \\
\left(\mathrm{kg} / \mathrm{m}^{3}\right)\end{array}$ & $\begin{array}{c}\text { Conductivity } \\
(\mathrm{W} / \mathrm{mK})\end{array}$ & $\begin{array}{c}\text { Price } \\
\text { Baht } / \mathrm{m}^{2}\end{array}$ & $\begin{array}{c}\text { Processing } \\
(\mathrm{Baht})\end{array}$ & \multicolumn{2}{|c|}{ Environmental friendly } \\
\cline { 5 - 8 } & & & & & $\begin{array}{c}\text { Emission Factor } \\
\left(\mathrm{kgCO} \mathrm{eq}^{2}\right.\end{array}$ & Recyclable \\
\hline $\begin{array}{l}\text { Plastic cladding } \\
\text { aluminum rod }\end{array}$ & Antirust & 2.22 & 0.023 & 15.6 & 1,070 & 0.43 & Yes \\
\hline Plastic bottle & Antirust & 1.22 & 0.15 & 0.5 & 482 & 1.91 & Yes \\
\hline Aluminum rod & Antirust & 2.00 & 0.023 & 12 & 962 & 0.78 & Yes \\
\hline
\end{tabular}

TABLE II

THE GROWTH RATE OF PLANT

\begin{tabular}{|c|c|c|c|c|c|c|}
\hline \multirow[b]{2}{*}{ Design } & \multicolumn{2}{|c|}{ month 1 June } & \multicolumn{2}{|c|}{ month 2 July } & \multicolumn{2}{|c|}{ month 3 August } \\
\hline & $\begin{array}{l}\text { Diameter of plant } \\
(\mathrm{cm})\end{array}$ & $\begin{array}{c}\text { Appearance of } \\
\text { holding equipment } \\
(\%)\end{array}$ & $\begin{array}{l}\text { Diameter of } \\
\text { plant } \\
(\mathrm{cm})\end{array}$ & $\begin{array}{c}\text { Appearance of } \\
\text { holding equipment } \\
(\%)\end{array}$ & $\begin{array}{l}\text { Diameter of } \\
\text { plant } \\
(\mathrm{cm})\end{array}$ & $\begin{array}{c}\text { Appearance of } \\
\text { holding equipment } \\
(\%)\end{array}$ \\
\hline Design 1 & 16 & 100 & 16 & 100 & 17 & 100 \\
\hline Design 2 & 16 & 100 & 16 & 100 & 16 & 100 \\
\hline Design 3 & 16 & 100 & 16 & 100 & 17 & 100 \\
\hline \multirow[b]{2}{*}{ Design } & \multicolumn{2}{|c|}{ month 4 September } & \multicolumn{2}{|c|}{ month 5 October } & \multicolumn{2}{|c|}{ month 6 November } \\
\hline & $\begin{array}{l}\text { Diameter of plant } \\
(\mathrm{cm})\end{array}$ & $\begin{array}{c}\text { Appearance of } \\
\text { holding equipment } \\
(\%)\end{array}$ & $\begin{array}{l}\text { Diameter of } \\
\text { plant } \\
(\mathrm{cm})\end{array}$ & $\begin{array}{c}\text { Appearance of } \\
\text { holding equipment } \\
(\%)\end{array}$ & $\begin{array}{l}\text { Diameter of } \\
\text { plant } \\
(\mathrm{cm})\end{array}$ & $\begin{array}{c}\text { Appearance of } \\
\text { holding equipment } \\
(\%)\end{array}$ \\
\hline Design 1 & 17 & 100 & 18 & 100 & 18 & 100 \\
\hline Design 2 & 16 & 100 & 17 & 100 & 17 & 100 \\
\hline Design 3 & 17 & 100 & 18 & 100 & 18 & 100 \\
\hline
\end{tabular}

\section{V.CONCLUSION}

The plant holding equipment designed in this study was made of low emission factor material. The thermal accumulation must be low in order to avoid the effect to the growth of plant. The plant holding equipment type one was made of the Aluminum rod with plastic cladding. The plant holding equipment type two was made of the recycled plastic bottle neck. The plant holding type three was made of the Aluminum rod. Even those three types were compatible with the roof, weather, and plant growth, the production, and cost will be the next issue to be concerned.

\section{REFERENCES}

[1] Laurel, K.G., Erik, B.E., Louis, S.S. and Michael, F.A. (2010). Carbon stable isotopic Composition of soluble sugars in Tillandsia epiphytes varies in response to shifts in habitat. PHYSIOLOGICAL ECOLOGY, 163, 583-590.

[2] Reynaldo, L.P. and others. (2009). Non-woody life-form contribution to vascular plant species richness in a tropical American forest. Plant Ecol, 201, 87-99. http://dx.doi.org/10.1007/s11258-008-9505-z 